\title{
Cadmium and phosphorus cycling in the water column of the South China Sea: The roles of biotic and abiotic particles
}

\author{
Tung-Yuan Ho ${ }^{\text {a }, *}$, Chen-Feng You ${ }^{b}$, Wen-Chen Chou ${ }^{c}$, Su-Cheng Pai ${ }^{d}$, Liang-Saw Wen ${ }^{d}$, David D. Sheu ${ }^{e}$ \\ a Research Center for Environmental Changes, Academia Sinica, Taipei, Taiwan \\ b Department of Earth Sciences, National Cheng Kung University, Tainan, Taiwan \\ c Institute of Marine Environmental Chemistry and Ecology, National Taiwan Ocean University, Keelung, Taiwan \\ ${ }^{\mathrm{d}}$ Institute of Oceanography, National Taiwan University, Taipei, Taiwan \\ e Institute of Marine Geology and Chemistry, National Sun Yat-Sen University, Kaohsiung, Taiwan
}

\section{A R T I C L E I N F O}

\section{Article history:}

Received 28 October 2008

Received in revised form 15 July 2009

Accepted 15 July 2009

Available online 23 July 2009

\section{Keywords:}

Cadmium

$\mathrm{Cd} / \mathrm{P}$ ratios

Lithogenic particles

Phytoplankton

Phosphorus

Sinking particle

South China Sea

\begin{abstract}
A B S T R A C T
The concentrations of cadmium, phosphorus, and aluminum in size-fractionated phytoplankton, zooplankton, and sinking particles are determined using ICPMS to evaluate the roles of biotic and abiotic particles on the cycling and ratios of $\mathrm{Cd}$ and $\mathrm{P}$ in the water column. Plankton were collected with a filtration apparatus equipped with 10-, 60-, and 150- $\mu \mathrm{m}$ aperture plankton nets on two occasions (2002 and 2006), and sinking particles were sampled by moored sediment traps deployed at depths of 120,600 , and $3500 \mathrm{~m}$ from 2004 to 2005. In contrast to what our previous study revealed, i.e., that most of the other bioactive trace metals in plankton were strongly correlated with abiotic $\mathrm{Al}$ and adsorbed on phytoplankton [Ho, T.Y., Wen, L.S., You, C.F., Lee, D.C., 2007. The trace metal composition of size-fractionated plankton in the South China Sea: biotic versus abiotic sources. Limnol Oceanogr 52,1776-88.], Cd/P ratios, ranging from 0.12 to $0.34 \mathrm{mmol} / \mathrm{mol}$ P, did not vary with $\mathrm{Al}$ and exhibited fairly consistent values among different sizes of plankton, showing that $\mathrm{Cd}$ was mostly incorporated on an intracellular basis. In terms of the sinking particles, fluxes in $\mathrm{Cd}$ and $\mathrm{P}$ as well as in $\mathrm{Cd} / \mathrm{P}$ ratios were strongly influenced by both biotic and abiotic particles. Overall, the $\mathrm{Cd} / \mathrm{P}$ ratios in the sinking particles ranged from 0.03 to $1.2 \mathrm{mmol} / \mathrm{mol}$, with the highest value observed in traps at $120 \mathrm{~m}$ during the productive season. The lowest value was observed in deep water during high flux periods for lithogenic particles. At surface depth, flux and Cd/P ratios were elevated during the most productive season in the region. The elevated ratios in the traps at $120 \mathrm{~m}$ were most likely related to preferential uptake of $\mathrm{Cd}$ for the dominant species (coccolithophores) during the productive period. Relatively, Cd/P ratios sharply decreased with increasing $\mathrm{Al}$ flux in deep water and ratios were much lower than the expected $\mathrm{Cd} / \mathrm{P}$ ratios obtained from the relative portion of lithogenic and biogenic particles, indicating that the adsorption of soluble P into lithogenic particles was significant in the deep water during high lithogenic particle flux periods. Using averaged annual fluxes and standing stock in the water column, the residence time of biogenic $\mathrm{Cd}$ and $\mathrm{P}$ are 0.10 and $0.20,250$ and 100 , and 9100 and 5000 years respectively in the top $120 \mathrm{~m}, 600 \mathrm{~m}$, and water column as a whole, also showing preferential removal for $\mathrm{Cd}$ in the euphotic zone but relatively higher removal rates for $\mathrm{P}$ in the deep water. Our study suggests that the shift in microalgal community structure along with input of lithogenic minerals are both potentially important factors in influencing $\mathrm{Cd} / \mathrm{P}$ ratios in oceanic water on a geological time scale.
\end{abstract}

(c) 2009 Elsevier B.V. All rights reserved.

\section{Introduction}

Cadmium, considered a toxic metal for terrestrial organisms, exhibits nutrient type distribution in the ocean (Boyle et al., 1976). Similar to major nutrients like nitrate and phosphate, internal cycling of cadmium in the ocean is controlled by biological activity, depleted by algal uptake in the euphotic zone and regenerated by bacteria mostly in surface waters (Boyle et al., 1976; Martin et al., 1976;

\footnotetext{
* Corresponding author. 128, Sec. 2, Academia Rd., Nankang, Taipei, 115, Taiwan. Tel.: +8862 26539885x858; fax: +88622783 3584 .

E-mail address: tyho@gate.sinica.edu.tw (T.-Y. Ho).
}

Bruland, 1980; Knauer and Martin, 1981). In addition to its vertical distribution, the horizontally segregation of $\mathrm{Cd}$ concentrations with increasing water age clearly shows that its horizontal cycling in the ocean also behaves like major nutrients (Bruland and Lohan, 2004). Cadmium appears to be the most eligible trace metal to join the Redfield ratio (Bruland et al., 1991; Kuss and Kremling, 1999; Ho et al., 2003; Ho, 2006). Relatively, phosphorus, a well-known essential major nutrient mainly used for reproduction and energy transfer in all organisms, has been traditionally regarded as a long term limiting nutrient (Redfield, 1958; Tyrrell, 1999). Its importance on limiting phytoplankton growth in the euphotic zone and its transformation processes in marine water columns have thus been relatively ignored 
(Benitez-Nelson, 2000). More recent studies have gradually revealed the importance and complexity of phosphorus in controlling algal growth and community structure in the ocean (e.g., Wu et al., 2000; Sañudo-Wilhelmy et al., 2001; Dyhrman et al., 2006).

With the highly correlated relationship between $\mathrm{Cd}$ and $\mathrm{P}$ in seawater, $\mathrm{Cd} / \mathrm{Ca}$ ratios in the hard parts of benthic foraminifera have been used as proxies to reconstruct $P$ concentrations in past oceanic environments (Boyle, 1988). Cd/P ratios in deep water, theoretically, are determined by biological fractionation of plankton in oceanic surface waters over long time scales. However, culture studies have revealed complicated interactions between phytoplankton and bioactive trace metals that may influence the correlation and cycling of $\mathrm{Cd}$ and $\mathrm{P}$ in marine water columns, especially in oceanic surface waters. For example, $\mathrm{Cd} / \mathrm{P}$ ratios in phytoplankton may be affected by physiological state of microalgae, phytoplankton phylum, the relative concentrations of $\mathrm{Cd}$ and $\mathrm{P}$ in seawater, or even the relative concentrations of other trace metals. Laboratory studies have revealed that $\mathrm{Cd}$ may be used as an alternative nutrient to replace $\mathrm{Zn}$ in carbonic anhydrase in marine diatoms when $\mathrm{Zn}$ is not available (Lane and Morel, 2000; Lane et al., 2005). Under low $\mathrm{Zn}$ and low $\mathrm{pCO}_{2}$ conditions, both laboratory and field studies have found that diatoms may take up more Cd (Lane and Morel, 2000; Price and Morel, 1990; Cullen and Sherrell, 2005). Culture and field studies also show that different algal species can have very different $\mathrm{Cd} / \mathrm{P}$ quotas (Ho et al., 2003, 2004; Abe, 2005; Finkel et al., 2007) and resistance to Cd toxicity (Payne and Price, 1999). Coccolithophore and dinoflagellates with cysts tend to have relatively high $\mathrm{Cd}$ quotas. Phytoplankton's community structure becomes an important factor in influencing $\mathrm{Cd}$ cycling and the $\mathrm{Cd} / \mathrm{P}$ ratio both in the surface oceans and deep waters. Algal Cd quota would also be elevated in regions with relatively high Cd concentrations, such as upwelling regions (Löscher et al., 1998; Sunda and Huntsman, 2000; Cullen and Sherrell, 2005). The interactive relationship among $\mathrm{Cd}, \mathrm{Zn}, \mathrm{Mn}$, and Fe can be important in deciding algal uptake of Cd (Sunda and Huntsman, 1996, 1998, 2000; Cullen and Sherrell, 2005; Cullen, 2006). These results imply that the $\mathrm{Cd} / \mathrm{P}$ ratios in deep waters might change in a long term when conditions affecting the $\mathrm{Cd} / \mathrm{P}$ ratios of biogenic particles in oceanic surface water change.

Although particles play a vital role in controlling trace metal distribution and cycling in the ocean (Turekian, 1977; Li, 1991), the role of particles on $\mathrm{Cd}$ and $\mathrm{P}$ cycling in marine water columns have been relatively ignored. Most previous studies on $\mathrm{Cd}$ and $\mathrm{P}$ have emphasized their correlation in dissolved form. In terms of vertical cycling, large biogenic particles, mostly composed of sizable plankton such as large diatoms, zooplankton and their hard parts, detritus, and fecal pellets, serve as the dominant components of sinking particles and thus are principal agents in transporting both major and trace elements from oceanic surface waters to deep waters (Fowler and Knauer, 1986; Alldredge and Jackson, 1995). Since the cycling of Cd and $\mathrm{P}$ is driven and transformed by biogenic particles generated in the euphotic zones (Martin and Broenkow, 1975; Bruland et al., 1978; Martin and Knauer, 1973), elemental concentrations in biogenic particles in oceanic surface waters not only reflect the interaction between plankton and seawater, but also provide fundamental information to study and model their vertical cycling processes in marine water columns (Martin and Knauer, 1973; Collier and Edmond, 1984; Bruland et al., 1991; Ho et al., 2003, 2007). In this study, we focus on determining the concentrations of $\mathrm{Cd}, \mathrm{P}$, and $\mathrm{Al}$ in particles, including phytoplankton and zooplankton in the surface water, and the sinking particles collected by sediment traps at three depths (120, 600 , and $3500 \mathrm{~m}$ ) in the northern South China Sea. Aluminum is used to evaluate the lithogenic source of trace metals in suspended particulate material and plankton samples (Ho et al., 2007). We especially examine the elemental composition of plankton larger than $10 \mu \mathrm{m}$ due to their importance in vertical transport of elements. We also determined the vertical fluxes of the two elements through sinking particles to elucidate their temporal and vertical cycling features and their relationship with biogenic and lithogenic particles. The published data of the dissolved concentrations of Cd and P (Wen et al., 2006) will be integrated with the data from this study to elucidate the roles of biotic and abiotic particles on the cycling of $\mathrm{Cd}$ and $\mathrm{P}$ and their residence time in different zones of the water column.

\section{Methods}

\subsection{Sampling site}

The sampling site, the South-East-Asian-Time-Series (SEATS), was located in the northern South China Sea basin (bottom depth $3783 \mathrm{~m}$ ) (Fig. 1). The northern South China Sea annually experiences the

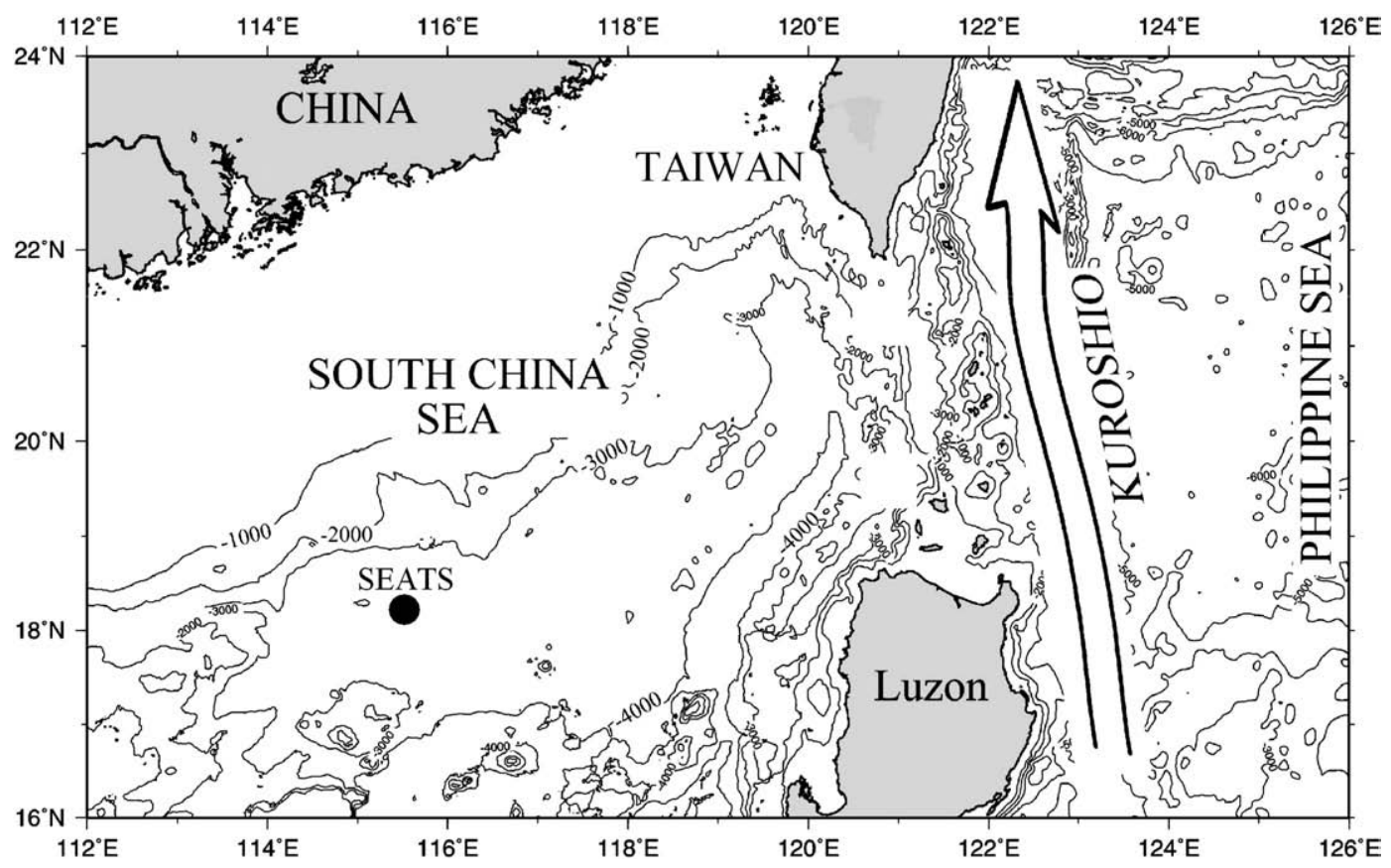

Fig. 1. Location of the sampling site in the South China Sea. 
northeastern monsoon in winter and southwestern monsoon in summer. Particles from biomass burning and anthropogenic materials from eastern and southern China and Southern Asia are brought to the region periodically (Lin et al., 2007). Our previous study revealed that the composition of many other bioactive trace metals in the sizefractionated plankton collected in the surface waters of the SEATS site were from extracellular inorganic particles adsorbed on cells (Ho et al., 2007). Several lines of evidences suggest that the extracellular metals were originally derived from anthropogenic aerosols containing highly soluble trace metals (Ho et al., 2007). Occasionally, the winter monsoon may also induce dust storms originating from the deserts of central China and input lithogenic particles into the surface water. This semi-enclosed deep water basin also lies close to regions with high fluvial input from the shelf, mainly from the Pearl River and Mekong River. Lateral transport of lithogenic particles from the continental shelf and break could be significant.

\subsection{Sampling of size-fractionated plankton}

The plankton samples were collected aboard two respective cruises during early spring (March 21 to 30, 2002) and fall (October 19 to 20, 2006). Plankton samples were collected using 20 L Tefloncoated Go Flo bottles (General Oceanics) mounted on a Teflon-coated rosette equipped with a modified epoxy coated Seabird CTD and Kevlar wire. Sampling of the size-fractionated plankton was especially focused at chlorophyll maximum depths. Six replicate casts were carried out at the chlorophyll maximum within $24 \mathrm{~h}$. For the oligotrophic waters like the South China Sea, where the highest total SPM is less than $0.5 \mathrm{mg} / \mathrm{L}$ in the surface water, filtering large volumes of seawater is required to obtain a sufficiently large amount of plankton biomass for trace metal analysis. We used a novel trace metal clean filtration device to gently filter $120-200 \mathrm{~L}$ of seawater and collect diverse sized plankton through two gravity filtration steps (Ho et al., 2007). Step one involved concentrating the plankton in the sampling bottles by guiding the seawater into the filtration apparatus. The gravity filtration plankton sampler is made of polycarbonate material and equipped with 150-, 60-, and 10- $\mu \mathrm{m}$ aperture changeable Nitex nets and three $100-\mathrm{mL}$ polyethylene sampling bottles in sequence, and acid-washed before each use. The design is shown in Ho et al. (2007). Before drawing seawater, the water spigots of six Go Flo bottles on the elevated rosette were first connected to the acid-washed C-flex tubes. The other ends of the C-flex tubes were then connected to the inflow ends of the size-fractionated filtration apparatus. The seawater in the bottles flowed through the six directional PTFE inlets and the water level was raised over the top bottle in the device, indicating that the intact size-fractionated biogenic particles had been gently separated through the nets; the particles then sank into the $100-\mathrm{mL}$ polyethylene bottles fixed at the bottom of the nets. The gentleness of the filtration process was witnessed by the live plankton observed in the sampling bottles after collection. Before processing the second filtration, the nets were sprayed with trace metal-clean filtered seawater to rinse out any plankton stuck on the inner surface of the nets. The concentrated plankton samples collected in the $100-\mathrm{mL}$ polyethylene bottles were then filtered again through an acid-washed filtration apparatus with pre-weighted acid-washed 47-mm 10- $\mu \mathrm{m}$ pore size polycarbonate filters. The samples in the two larger fractions were then passed through the filters in less than a minute under gravity or very low vacuum. The biogenic particles on the filters were quickly rinsed with Milli-Q water to remove seawater residue and thereby diminish the influence of dry-out salts in analysis. The rinsing step was kept to a few seconds to avoid causing the breakup of the fragile plankton. The folded filters with the particles were stored in acid-washed pre-weighted polyethylene culture dishes and kept in a freezer on board to be brought back to a land-based laboratory for further processing. All SPM (Suspended Particulate Material) samples were collected in the trace metal-clean laminar flow bench on board through $0.4-\mu \mathrm{m}$ acid-washed polycarbonate filters under $100-\mathrm{mm} \mathrm{Hg}$ vacuum conditions using 2 to $4 \mathrm{~L}$ of seawater. More detailed information about the filtration device and the filtration procedures is described in Ho et al. (2007).

\subsection{Sampling of sinking particles}

Time series moored sediment traps were deployed at the SEATS station $\left(115.7^{\circ} \mathrm{E} ; 18.2^{\circ} \mathrm{N}\right)$ around the depths of 120,600 , and $3500 \mathrm{~m}$ on two occasions. The first deployment lasted from August 8, 2004 to February 16, 2005; the second from April 1, 2005 to October 10, 2005. Two types of French time series sediment traps (Technicap PPS $3 / 3$ and PPS 5/2) were used in the deployment, with 1.00 and $0.125 \mathrm{~m}^{2}$ cone areas and 8- and 16-day collection intervals for each cup, respectively. The current velocities in the water column of the sampling site are generally low. The averaged zonal velocities ( $u$ and v) at $120 \mathrm{~m}$ in August and December were around -4 and $4 \mathrm{~cm} / \mathrm{s}$, and -25 and $-2 \mathrm{~cm} / \mathrm{s}$, obtained from field current data averaged over the period 1999 to 2003 (Wu et al., 2005). The pressure data of the ADCP installed with the traps show that variability of the trap depth was limited. The averaged corresponding depths of the three traps with one standard deviation were $123 \pm 17,625 \pm 6$, and $3454 \pm 2 \mathrm{~m}$ for the first deployment and $84 \pm 31,529 \pm 6$, and $3487 \pm 0.8 \mathrm{~m}$ for the second deployment, respectively. Although trapping efficiency was not directly determined in this study, we found that the organic carbon fluxes estimated by the P fluxes obtained from the trap samples in this study were comparable to nitrate-based new production (Chen, 2005), suggesting that the trapping efficiency may be considerably high. After retrieving the traps on board, the sample bottles were detached and stored in a cold room below $4{ }^{\circ} \mathrm{C}$ on board for further processing on land.

\subsection{Pretreatment and analysis}

After being freeze-dried and weighed, the filters with the plankton particles were digested in $1 \mathrm{ml} 8 \mathrm{~N}$ super pure nitric acid (SeaStar) in $20 \mathrm{ml}$ Teflon vials at $120^{\circ} \mathrm{C}$ on a hot plate for $24 \mathrm{~h}$ (Ho et al., 2003). After diluting the digested solution to $10 \mathrm{ml}$ with Milli-Q water and removing the filter, the solution was centrifuged to remove any particulate residues. In terms of sinking particles, the supernatant in each cup was first removed by plastic syringe and stored in a refrigerator for further processing. Particle samples were divided into six portions using a perimatic peristaltic pump dispenser (Jencons Ltd.). The subsamples were then passed through $1 \mathrm{~mm}$ nylon mesh to remove swimmers and large zooplankton. Any other swimmers, which passed through the sieve, were manually picked. A small portion of well-mixed particle samples were sampled and filtered with $0.2-\mu \mathrm{m}$ acid-washed polycarbonate filter under vacuum. The samples on the filters were quickly rinsed with Milli-Q water a couple of times to remove sea salts. After being freeze-dried and weighed, the filters were soaked in a mixture of 0.9 -ml super pure nitric acid and 0.1-ml super pure hydrofluoric acid (Seastar) in 10-ml microwavable Teflon vials. The filters with particles and the blank filters were digested in a microwave oven (MARS, CEM) at $180^{\circ} \mathrm{C}$ for $15 \mathrm{~min}$ with a 10 -minute ramp from room temperature to $180^{\circ} \mathrm{C}$. After complete digestion, the samples were evaporated to be almost dry on hot plates at $80{ }^{\circ} \mathrm{C}$ under a trace metal-clean hood. The dried samples were added with super pure nitric acid and diluted sequentially with Milli-Q water to obtain samples in 3\% nitric acid solution, which were ready for ICPMS analysis.

Due to consideration given for determining $\mathrm{Hg}$ species by other researchers in the sediment trap study, saline solution without $\mathrm{Hg}$ was used as the trap cup solution. It should be noted that even with preservative added, significant amounts of $\mathrm{Cd}$ and $\mathrm{P}$ in particles can become soluble from sinking particles during long term storage in sediment traps (Knauer and Martin, 1981). It is thus essential to determine and include the soluble portion of $\mathrm{P}$ and $\mathrm{Cd}$ in the supernatant to obtain accurate total particle fluxes (Knauer and Martin, 
1981). We observed significant amounts of $\mathrm{P}$ and Cd existing in the supernatant solution, particularly in the samples from shallow depths. Supernatant samples were first diluted 100 -fold and treated with $1200 \mathrm{~W}$ UV radiation for $12 \mathrm{~h}$ to decompose soluble organic matter in the diluted supernatant. Phosphorus concentrations in the diluted supernatant solution were analyzed by both a spectrophotometer and ICPMS. Using the corresponding concentrations obtained from the two methods as the data for $x$ and $y$ axes, the slope of the correlation line was 1.1, showing good accuracy for P analysis in the supernatant. The concentrations of $\mathrm{Al}, \mathrm{P}$, and $\mathrm{Cd}$ in the various particle samples and the concentrations of $\mathrm{Cd}$ in the diluted supernatant solution were determined by using a sector field high resolution ICPMS (Element 2 or Element XR, Thermo Scientific), fitted with a desolvation system (ESI). The analysis was conducted with sensitivity higher than $10^{6}$ counts per second for $10 \mathrm{ppb}$ In under medium resolution. The sensitivity and stability of the instrument were adjusted to optimal conditions before analysis. External and internal standards were both applied for concentration quantification. The details of the precision, accuracy, and detection limit of the method were described in Ho et al. (2003, 2007).

\section{Results and discussions}

\section{1. $C d, P$, and $A$ in SPM and plankton}

Aluminum and phosphorus, with their contrasting known abundance in both lithogenic and biogenic particles correspondingly, are used to evaluate the relative biotic and abiotic sources for trace metals in SPM and plankton samples (Ho et al., 2007). By assuming constant trace metal composition in both biogenic and abiogenic particles, their quantitative relationship can be obtained in the following mass balance formula:

$[M]=a[P]+b[A l]$

[M] total concentration of metal in particulate matter

[P] phosphorus concentration in biogenic particles

[Al] aluminum concentration in abiogenic particles

a P-normalized metal quotas in biogenic particles

$b \quad$ Al-normalized metal quotas in abiogenic (assuming lithogenic) particles

Although biogenic hard parts (e.g., $\mathrm{CaCO}_{3}$ and $\mathrm{SiO}_{2}$ ) contribute a significant portion in biogenic particles in terms of mass, the concentrations of trace metals and $\mathrm{P}$ in the hard parts are so low that the contribution of these elements in the hard parts to the overall biogenic particles are ignorable. The $\mathrm{M} / \mathrm{P}$ ratios in biogenic organic particles may reasonably represent the overall ratios in biogenic particles. The relative influence of biogenic and lithogenic sources on $\mathrm{Cd}$ in the SPM is first evaluated by examining the vertical distribution patterns for particulate $\mathrm{Al}$ and $\mathrm{P}$, coupled with the concentrations of SPM and Chlorophyll- $a$ in the SPM of the surface waters (Fig. 2). The vertical concentration of particulate $\mathrm{Al}$ increased with depth in the top $200 \mathrm{~m}$. The total SPM, chlorophyll- $a$, and particulate P exhibited a similar distribution pattern, all with a maximum at depth of $60 \mathrm{~m}$, showing that most of the particles at the chlorophyll maximum depth were composed of phytoplankton (Ho et al., 2007). The concentrations of Cd in the SPM also exhibited a similar distribution pattern to chlorophyll- $a$, indicating that the particulate $\mathrm{Cd}$ was also associated with the phytoplankton. To illustrate the relative contribution of biotic and abiotic particles, the metal quotas of the samples are expressed by plotting the ratios in log scale in the following reorganized formats of the above equation.

$[M] /[P]=a+b[A l] /[P]$

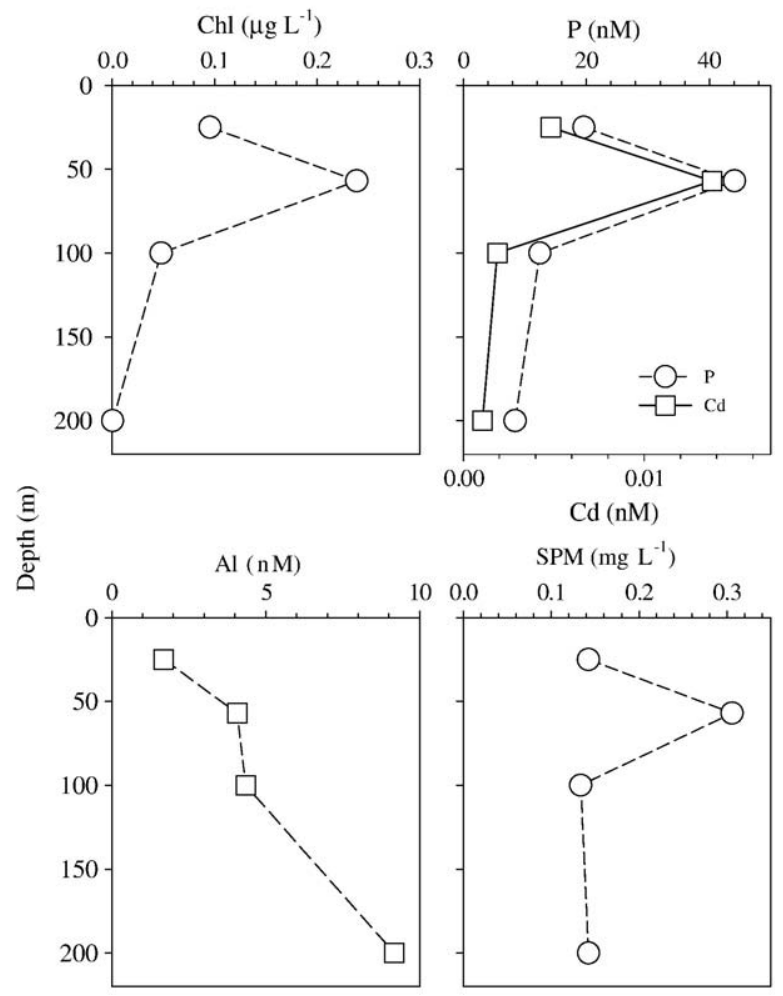

Fig. 2. The vertical profiles of P, Cd, Al, and Chlorophyll- $a$ in SPM, and the total SPM collected in the surface water of the SEATS site.

The relationship among the ratios of $\mathrm{Cd} / \mathrm{P}$ and $\mathrm{Al} / \mathrm{P}$ is shown in Fig. 3, which includes the data obtained from the cruises of March 2002 and October 2006 (Table 1). The three points in each figure represent the averaged metal quotas in each size fraction, from the

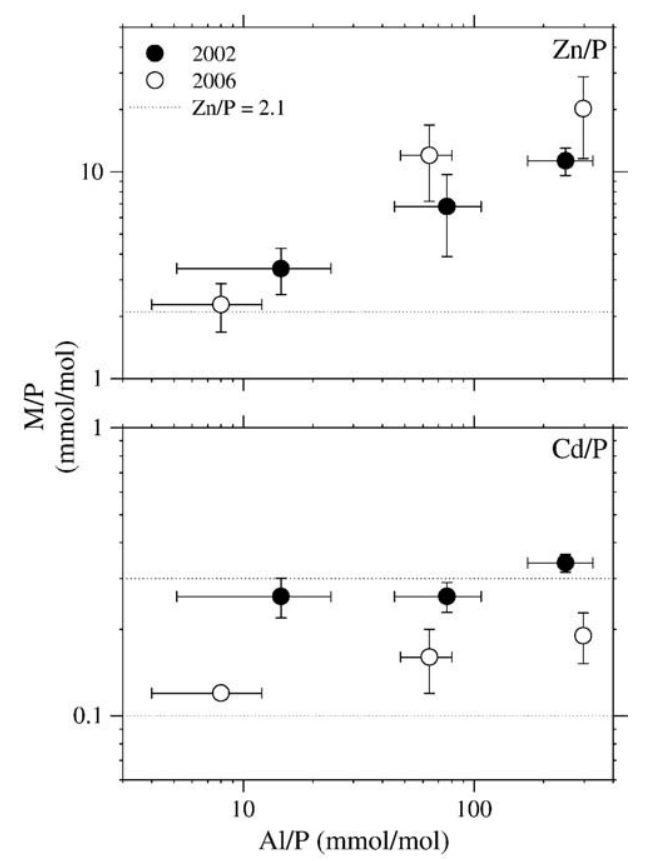

Fig. 3. The correlation of $\mathrm{Cd} / \mathrm{P}$ or $\mathrm{Zn} / \mathrm{P}$ to $\mathrm{Al} / \mathrm{P}(\mathrm{mmol} / \mathrm{mol})$ in the three size-fractionated plankton, $10-60 \mu \mathrm{m}, 60-150 \mu \mathrm{m}$, and larger than $150 \mu \mathrm{m}$, which were collected at the chlorophyll maximum depth of the SEATS site in March 2002 and October 2006. Each point with 1 standard deviation as error bars $(n=3$ to 5$)$ stands for the average $\mathrm{M} / \mathrm{P}$ ratios for each size fraction. The smaller the plank sizes were the higher the $\mathrm{Al} / \mathrm{P}$ ratios were. The dotted lines in the figure stand for the averaged $\mathrm{Zn}$ and $\mathrm{Cd}$ quotas in marine plankton assemblages obtained from reliable field and laboratory studies (Ho, 2006). 
Table 1

The elemental composition ( $\mu \mathrm{g} \mathrm{g}^{-1}$ to dry weight) in the SPM and size-fractionated plankton.

\begin{tabular}{|c|c|c|c|c|c|c|c|c|}
\hline Date & $\begin{array}{l}\text { Size range } \\
(\mu \mathrm{m})\end{array}$ & $\begin{array}{l}\text { depth } \\
\text { (m) }\end{array}$ & $\begin{array}{l}\text { Dry wt. } \\
\text { (mg) }\end{array}$ & $\begin{array}{l}\text { Sample } \\
\text { vol. (L) }\end{array}$ & $\mathrm{Al}$ & $\mathrm{Cd}$ & $\mathrm{P}$ & $\mathrm{Zn}$ \\
\hline \multirow[t]{21}{*}{ March 2002} & $>0.4$ & 25 & 0.60 & 4.2 & 317 & 3.8 & 4233 & 49 \\
\hline & $>0.4$ & 57 & 0.61 & 2.1 & 442 & 4.9 & 4006 & 78 \\
\hline & $>0.4$ & 57 & 0.56 & 1.7 & 364 & 5.6 & 4711 & 53 \\
\hline & $>0.4$ & 57 & 0.64 & 2.3 & 292 & 4.9 & 4936 & 61 \\
\hline & $>0.4$ & 100 & 0.58 & 4.3 & 878 & 1.6 & 2887 & 87 \\
\hline & $>0.4$ & 200 & 0.59 & 4.2 & 1757 & 0.9 & 1853 & 94 \\
\hline & $10-60$ & 61 & 0.98 & 120 & 772 & 7.8 & 6228 & 168 \\
\hline & $10-60$ & 56 & 1.79 & 120 & 751 & 6.0 & 5548 & 165 \\
\hline & $10-60$ & 50 & 1.26 & 120 & 1325 & 5.5 & 4569 & 104 \\
\hline & $10-60$ & 50 & 1.00 & 120 & 1225 & 6.2 & 4657 & 93 \\
\hline & $10-60$ & 60 & 1.41 & 120 & 995 & 4.4 & 3531 & 77 \\
\hline & $60-150$ & 61 & 1.29 & 120 & 527 & 8.1 & 9737 & 197 \\
\hline & $60-150$ & 56 & 0.67 & 120 & 783 & 7.6 & 6715 & 159 \\
\hline & $60-150$ & 50 & 0.92 & 120 & 438 & 7.4 & 7989 & 91 \\
\hline & $60-150$ & 50 & 0.77 & 120 & 376 & 8.4 & 8619 & 100 \\
\hline & $60-150$ & 60 & 0.85 & 120 & 505 & 6.6 & 7471 & n.a. ${ }^{a}$ \\
\hline & $>150$ & 61 & 10.5 & 120 & 45 & 18.4 & 25,474 & 119 \\
\hline & $>150$ & 56 & 1.22 & 120 & 186 & 9.5 & 9232 & 94 \\
\hline & $>150$ & 50 & 1.80 & 120 & 141 & 13.0 & 11,588 & 69 \\
\hline & $>150$ & 50 & 1.91 & 120 & 65 & 7.3 & 9026 & 66 \\
\hline & $>150$ & 60 & 3.04 & 120 & 166 & 12.0 & 11,893 & 84 \\
\hline \multirow[t]{9}{*}{ October 2006} & $10-60$ & 58 & 0.26 & 100 & 2943 & 8.9 & 11,147 & 706 \\
\hline & $10-60$ & 58 & 0.30 & 100 & 1897 & 5.9 & 7839 & 278 \\
\hline & $10-60$ & 58 & 0.67 & 200 & 1929 & 4.0 & 7120 & 209 \\
\hline & $60-150$ & 58 & 0.46 & 100 & 304 & 3.7 & 4771 & 172 \\
\hline & $60-150$ & 58 & 0.60 & 100 & 438 & 3.2 & 6901 & 165 \\
\hline & $60-150$ & 58 & 0.70 & 200 & 470 & 5.8 & 11,652 & 145 \\
\hline & $>150$ & 58 & 1.37 & 100 & 80 & 5.5 & 12,225 & 67 \\
\hline & $>150$ & 58 & 1.87 & 100 & 69 & 7.4 & 17,008 & 53 \\
\hline & $>150$ & 58 & 1.75 & 200 & 122 & 5.1 & 11,824 & 64 \\
\hline
\end{tabular}

a.a.: data not available.

smallest to the largest with the increasing $\mathrm{Al} / \mathrm{P}$ ratios. Our previous study found that the metal composition in the phytoplankton collected in the same sampling site was mainly dominated by extracellularly adsorbed abiotic forms and the metals were highly likely derived from anthropogenic aerosols containing abundant dissolvable trace metals (Ho et al., 2007). Using Zn as an example, the Zn quota in plankton increased with increasing abiotic $\mathrm{Al} / \mathrm{P}$ ratios, showing that $\mathrm{Zn}$ was strongly associated with abiotic $\mathrm{Al}$ (Ho et al., 2007). The trace metals distributed in the same way as $\mathrm{Zn}$ included: Ti, V, Cr, Mn, Fe, $\mathrm{Co}, \mathrm{Ni}$, and $\mathrm{Cu}$. In contrast, the correlation of $\mathrm{Cd}$ with $\mathrm{Al}$ was different from other metals. Despite $\mathrm{Al} / \mathrm{P}$ ratios increasing from 14,76 , to $248 \mathrm{mmol} / \mathrm{mol}$ in the three fractions of plankton in 2004, respectively, the $\mathrm{Cd}$ quotas were fairly consistent, with the average of $0.26 \pm 0.04$ (1SD), $0.26 \pm 0.03$, to $0.34 \pm 0.02(\mathrm{mmol} / \mathrm{mol} \mathrm{P})$ for the plankton from the largest to the smallest. In 2006, when $\mathrm{Al} / \mathrm{P}$ increased from 8,62 , to 287 , the Cd quota only varied from $0.12 \pm 0.003,0.16 \pm 0.05$, to $0.19 \pm$ 0.03 , respectively. Compared to the one order of magnitude increase for $\mathrm{Zn} / \mathrm{P}$ quota, the Cd/P quota was fairly consistent, insignificant or slightly higher in the smallest fraction of the plankton. The relatively consistent $\mathrm{Cd} / \mathrm{P}$ quota in the diverse plankton with increasing $\mathrm{Al}$ indicates that most of the $\mathrm{Cd}$ in the suspended particles was located in plankton intracellularly but not adsorbed extracellularly, and the $\mathrm{Cd}$ bio-accumulation through the microbial food web was ignorable. Although there was no significant variability for the $\mathrm{Zn} / \mathrm{P}$ and $\mathrm{Al} / \mathrm{P}$ ratios in individual plankton fractions between the two cruises, the $\mathrm{Cd} / \mathrm{P}$ ratios were lower in the samples collected in October 2006. As pointed out in the introduction section, Cd quota among different algal phyla can be very different. The Cd quota in coccolithophore is much higher than for diatoms when they are grown under identical culture medium, (Sunda and Huntsman, 2000; Ho et al., 2003). The dominance of coccolithophore during the productive winter season in the South China Sea basin (Chen et al., 2007) was likely to be the major cause of elevated Cd/P in the plankton samples of March 2002.

\section{2. $C d$ and $P$ fluxes}

Seasonal variability of primary production has been reported at the sampling site (Chen, 2005; Tseng et al., 2005), with highest production during winter time and lowest during the summer season. Seasonal patterns of organic matter fluxes were recorded in the traps at $120 \mathrm{~m}$, with a sharp increase for both Cd and P from December 2004 to February 2005 when primary production was highest (Fig. 4). The depth of the first trap was close to the bottom depth of the euphotic zone (Chen, 2005), where the organic carbon fluxes estimated from sinking particles may reasonably represent new production in the euphotic zone (Pace et al., 1987). New production in the euphotic zone was estimated by multiplying the export P fluxes obtained from the $120 \mathrm{~m}$ traps with the Redfield ratio, which ranged from 0.05 to $0.85 \mathrm{~g} \mathrm{Cm}^{-2} \mathrm{~d}^{-1}$ among the lowest and highest seasons, compatible to the new production estimated by nitrate uptake at the same sampling site, which ranged from 0.03 to $0.26 \mathrm{gCm}^{-2} \mathrm{~d}^{-1}$ during the lowest to highest production periods (Chen, 2005). It should be noted that new production estimated by nitrate uptake was based on 1 to 2 cruise studies in each season, and these may not have been able to catch the maximum production period as shown in Fig 4. In general, these two new production estimates were consistent with each other while considering the possible uncertainties in both analyses.

At the two deeper depths, the fluxes in $\mathrm{P}$ and $\mathrm{Cd}$ decreased exponentially. The average flux of $P$ in the $600 \mathrm{~m}$ trap was only about one tenth of flux at $120 \mathrm{~m}$, ranging from 5 to $50 \mu \mathrm{mol} / \mathrm{m}^{2} / \mathrm{d}$. Relatively, Cd flux decreased even more sharply, ranging from 1 to $10 \mathrm{nmol} / \mathrm{m}^{2} / \mathrm{d}$ overall. The $\mathrm{Cd}$ and $\mathrm{P}$ fluxes in the deepest trap decreased to $0.4-2.4$ $\left(\mathrm{nmol} / \mathrm{m}^{2} / \mathrm{d}\right)$ and $4-12\left(\mu \mathrm{mol} / \mathrm{m}^{2} / \mathrm{d}\right)$, respectively. Except for elevated fluxes during December 2004 to January 2005 in the middle trap, there was no strong seasonal variability for fluxes observed in the deeper water. An abnormally high Al flux was observed during the end

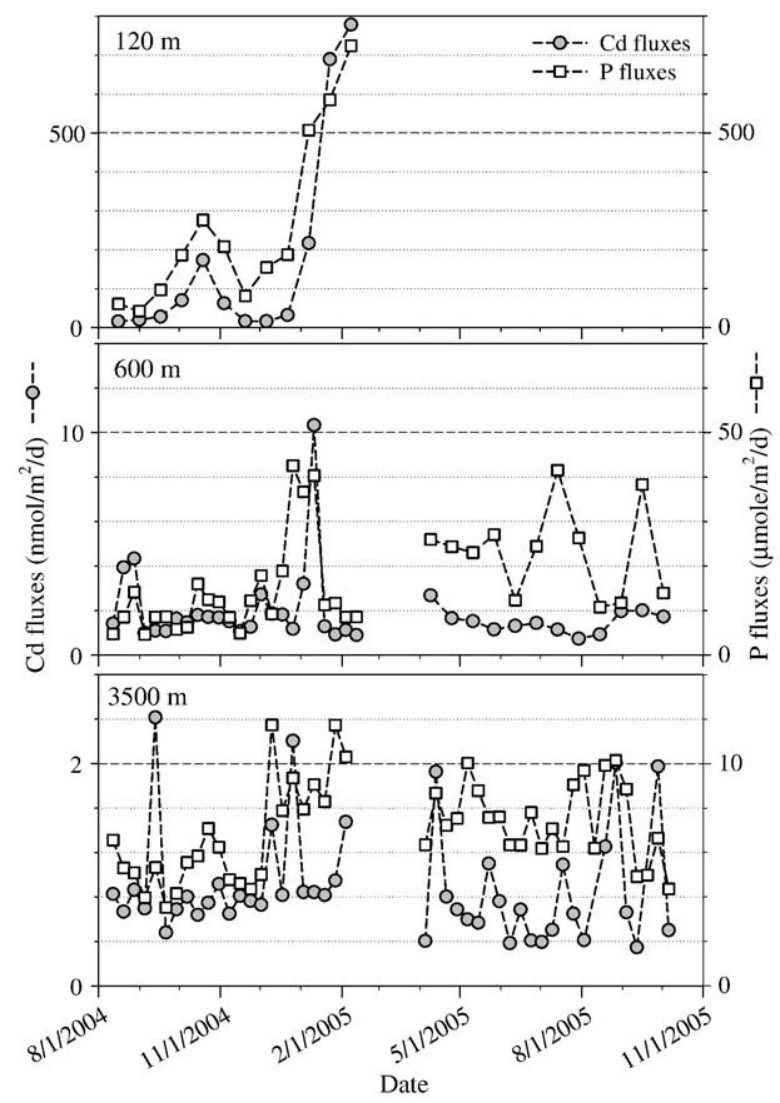

Fig. 4. The vertical and temporal variability of $\mathrm{Cd}$ and $\mathrm{P}$ fluxes determined by sinking particles collected at the three depths of 120,600 , and $3500 \mathrm{~m}$ of the SEATS site. 
of December 2004 when the South Asia Tsunami occurred. Although the abiotic P portion estimated from Al fluxes only accounted for $10 \%$ of the total sinking P pool (Fig. 5), the fluxes of P, but not $\mathrm{Cd}$, were significantly elevated in the two deeper traps (Fig. 4), indicating a preferential removal of $P$ during the tsunami event. Based on the sinking fluxes and the standing stock in seawater (Wen et al., 2006), the residence time of biogenic $\mathrm{Cd}$ and $\mathrm{P}$ in the zonation of $0-120 \mathrm{~m}$, $0-600 \mathrm{~m}$, and the whole water column are 0.10 and $0.20,250$ and 100 , 9100 and 5000 years respectively according to box modeling. The residence time shows that the sinking rate of $\mathrm{Cd}$ in the euphotic zone was higher than $\mathrm{P}$ but the removal rates of $\mathrm{P}$ in the thermocline and the deep water were higher than $\mathrm{Cd}$.

The organic carbon estimated from the biogenic P fluxes of the deepest trap may represent the net organic carbon export of the water column vertically. The portion of abiotic $P$ in the deeper water needs to be excluded while estimating organic carbon fluxes (Fig. 5). The percentage of abiotic $\mathrm{P}$ and $\mathrm{Cd}$ ranged from less than $2 \%$ in the traps at $120 \mathrm{~m}$ to about $20-30 \%$ in the bottom trap (Fig. 5). After subtracting the abiotic portion, the annual biogenic P flux in the deepest trap was $1.9 \mathrm{mmol} / \mathrm{m}^{2} / \mathrm{yr}$, obtained by multiplying 365 by the averaged daily biogenic P flux $5.3 \mu \mathrm{mol} / \mathrm{m}^{2} / \mathrm{d}$, which is equivalent to about $0.20 \mathrm{~mol} / \mathrm{m}^{2} / \mathrm{yr}$ or $6 \mathrm{~g} / \mathrm{m}^{2} / \mathrm{yr}$ organic carbon export to the sediment.

\section{3. $C d / P$ ratios in sinking particles and seawater}

Dramatic seasonal variabilities of $\mathrm{Cd} / \mathrm{P}$ ratios were also observed in sinking particles collected by the traps at $120 \mathrm{~m}$ (Fig. 6), ranging from 0.1 to $1.2(\mathrm{mmol} / \mathrm{mol})$. In particular, there was a sharp increase from early December of 2004 to late February of 2005. Despite the low Cd/P ratio being seemingly related to the relatively high $\mathrm{Al}$ fluxes around December, the relative contribution of lithogenic Al fluxes on $\mathrm{Cd} / \mathrm{P}$ ratios were ignorable in the traps at $120 \mathrm{~m}$ (Fig. 6). The lithogenic $\mathrm{P}$ and $\mathrm{Cd}$ calculated by using $\mathrm{Al}$ fluxes shows that lithogenic $\mathrm{Cd}$ and $\mathrm{P}$
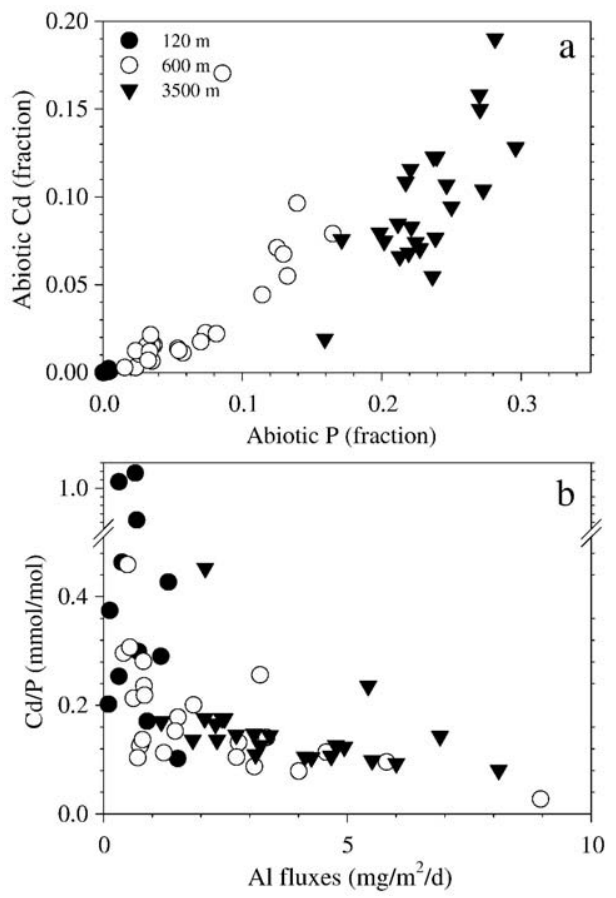

Fig. 5. (a) The percentage of the abiotic $\mathrm{Cd}$ and $\mathrm{P}$ in the sinking particles, estimated by $\mathrm{Al}$ concentrations in the sinking particles using the $\mathrm{Cd} / \mathrm{Al}$ and $\mathrm{P} / \mathrm{Al}$ standard ratios in crustal composition, which are 0.0006 and $11(\mathrm{mmol} / \mathrm{mol}$ to $\mathrm{Al})$, respectively (Taylor, 1964). The P/Al ratios in the sediments of the South China Sea were reported by Calvert et al. (1993). The averaged $\mathrm{P} / \mathrm{Al}$ ratio in the sediments collected from two stations (GGC1 and GGC2 in Table 1), close to our sampling site, was $11.2 \pm 2.7$, extremely close to the standard ratio. (b) The comparison of the $\mathrm{Cd} / \mathrm{P}$ ratios in the sinking particles with Al fluxes.

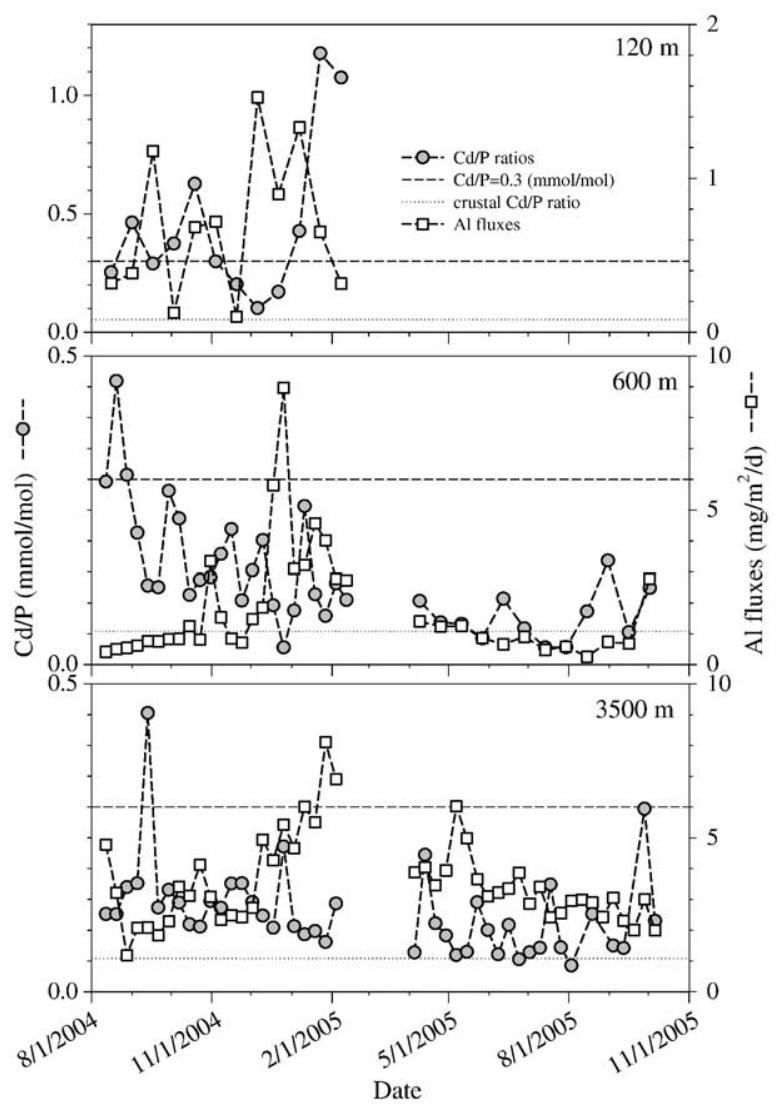

Fig. 6. The vertical and temporal variability of $\mathrm{Al}$ fluxes and $\mathrm{Cd} / \mathrm{P}$ ratios in the sinking particles collected at the three depths of 120,610 , and $3500 \mathrm{~m}$ of the SEATS site.

were less than $2 \%$ of the total $\mathrm{P}$ and $\mathrm{Cd}$. The direct influence of the abiotic particles on the $\mathrm{Cd} / \mathrm{P}$ ratios may be excluded but lithogenic particles may have indirect effect on changing the ratios, e.g., through $\mathrm{P}$ adsorption on mineral clays. At the two deeper depths, lithogenic particles play an important role in deciding $\mathrm{Cd} / \mathrm{P}$ ratios, witnessed by the reciprocal correlation between $\mathrm{Al}$ fluxes and $\mathrm{Cd} / \mathrm{P}$ ratios shown in Fig. 5. The $\mathrm{Cd} / \mathrm{P}$ ratios in the sinking particles collected at $600 \mathrm{~m}$, range from 0.03 to $0.48 \mathrm{mmol} / \mathrm{mol}$ without showing any seasonal pattern. The highest ratios were observed between August and September in 2004, coinciding with the lowest Al fluxes. The lowest ratio was observed during the end of December 2004, coinciding with the highest Al fluxes when the South Asia Tsunami happened. The $\mathrm{Cd} / \mathrm{P}$ ratios in the deepest trap generally ranged between 0.04 and $0.20 \mathrm{mmol} / \mathrm{mol}$ with a couple of high value points. The $\mathrm{Cd} / \mathrm{P}$ ratios in the sinking biogenic particles in the top two traps generally ranged from 0.1 to $1.0 \mathrm{mmol} / \mathrm{mol}$ (Fig. 4) with an average ratio of around 0.2 (Fig. 3); the typical Cd/P ratio in lithogenic particles is around $0.05 \mathrm{mmol} / \mathrm{mol}$ (Taylor, 1964). Since the estimated lithogenic P and $\mathrm{Cd}$ accounted for a significant but minor portion $(<30 \%)$ of the total $\mathrm{P}$ and $\mathrm{Cd}$ in the sinking particles (Fig. 5), the overall $\mathrm{Cd} / \mathrm{P}$ ratios in the sinking particles were supposed to be close to the ratios of the end member of the biogenic ratio (e.g., $0.2-0.3 \mathrm{mmol} / \mathrm{mol}$ ) instead of the lithogenic ratios (e.g., $0.05 \mathrm{mmo} / \mathrm{mol}$ ). The abnormally low $\mathrm{Cd} / \mathrm{P}$ ratios in the sinking particles observed during the high Al flux periods, which were close to or even lower than the $\mathrm{Cd} / \mathrm{P}$ ratio in typical lithogenic particles $(0.05 \mathrm{mmol} / \mathrm{mol})$, indicates a strong preferential $\mathrm{P}$ removal by lithogenic particles in deep water. The most likely mechanism for the $\mathrm{P}$ removal is phosphate adsorption with clay minerals (Edzwald et al., 1976). The phosphate adsorption capacities of kaolinite, montmorillonite, and illite in seawater solution were 0.10 , 0.75 , and $2.5 \mathrm{mg} \mathrm{P} / \mathrm{g}$ clay mineral, respectively (Edzwald et al., 1976). Using $5 \mathrm{mg} / \mathrm{m}^{2} / \mathrm{d}$ Al fluxes as the averaged value in deep water, 
roughly equivalent to $60 \mathrm{mg} / \mathrm{m}^{2} / \mathrm{d}$ lithogenic mineral fluxes, and simply assuming P adsorption capacity to be $1 \mathrm{mg} \mathrm{P} / \mathrm{g}$ clay minerals, the corresponding $P$ adsorption would be around $2 \mu \mathrm{mol} / \mathrm{m}^{2} / \mathrm{d}$, accounting for a significant amount of the total $P$ fluxes observed in the deep water. This estimate appears to be preliminary. However, the results indicate that the role of lithogenic particles on removing soluble $\mathrm{P}$ and influencing $\mathrm{Cd} / \mathrm{P}$ ratios in sinking particles and seawater can be significant, particularly over long time periods. To further test our argument, we have studied the data sets published by Noriki et al. (1999). The sinking particles in the study were collected by sediment traps deployed in the Pacific Ocean at depths ranging from 1500 to $5100 \mathrm{~m}$ at three different stations, where the relative percentages of the organic matter and biogenic hard parts in the sinking particles did not change much. Once again, we have observed a strong exponential decay relationship between the $\mathrm{Cd} / \mathrm{P}$ ratios and the clay percentage (Fig. 7), strongly supporting our argument.

The other factor which may influence the $\mathrm{Cd} / \mathrm{P}$ ratios in particles and seawater would be the community structure of phytoplankton. Culture studies have clearly shown that the variability of Cd quotas in 5 major marine algae phyla grown in identical medium ranged up to two orders of magnitude, from 0.01 to $1.0 \mathrm{mmol} / \mathrm{mol} \mathrm{P}$ (Ho et al., $2003,2004)$. This two orders of magnitude range was largest among the trace metals measured, including: $\mathrm{Fe}, \mathrm{Mn}, \mathrm{Zn}, \mathrm{Cu}, \mathrm{Co}, \mathrm{Cd}$, and $\mathrm{Mo}$ (Ho et al., 2003). The ratios were generally high for coccolithophores and low for diatom and chlorophyta. Culture study by Sunda and Huntsman (2000) also showed much higher Cd quota in coccolithophore than in diatom. Dinoflagelates with cysts can have high Cd quotas intracellularly (Ho et al., 2003). Once the algal community structure shifts, it is expected that one would observe different $\mathrm{Cd} / \mathrm{P}$ ratios in plankton and thus resultant sinking organic particles. With relatively low nitrate concentrations in the surface water during the productive winter season, it is known that coccolithophore is the dominant algal species during the winter season in the South China Sea (Chen et al., 2007), which generally happens from January to March. When the northeastern monsoon starts to blow in October and brings the nutrients to the surface water to induce the growth of diatom, the $\mathrm{Cd} / \mathrm{P}$ ratios in sinking particles, which are supposedly dominated by diatoms, would be relatively low. After nitrate concentrations go down, the succession of coccolithophores would follow and dominate (Chen et al., 2007). The change of Cd/P ratios from December to February 2005 may thus be caused by the succession of microalgal species. Field studies also support the argument. Nolting et al. (1999) reported that Cd removal by phytoplankton during Emiliania huxleyi bloom was more significant than for other bioactive trace metals. Ho (2006) has compiled a few reliable field studies and reported that Cd quotas in the phytoplankton

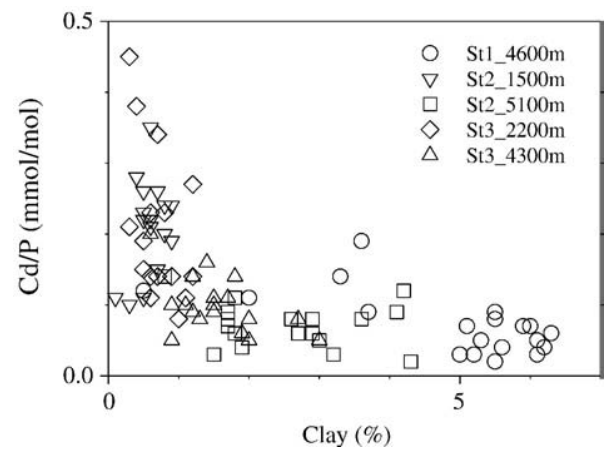

Fig. 7. The comparison of $\mathrm{Cd} / \mathrm{P}$ ratios with the clay percentage in the sinking particles collected by the sediment traps deployed in the deep waters of the Pacific Ocean (Noriki et al., 1999). The sampling sites from 1 to 3 are located at $48^{\circ} \mathrm{N}, 13^{\circ} \mathrm{N}$, and $0^{\circ} \mathrm{N}$, along $175^{\circ} \mathrm{E}$, respectively. In addition to clay minerals, opal, calcium carbonate, and organic material were also determined. The major components in the sinking particles were the hard parts, accounting for 80 to $90 \%$ of the total mass. The mass percentage of organic matter was generally around $10 \%$ with limited variability for most of the samples. samples collected in various oligotrophic open ocean regions were remarkably consistent, ranging from 0.44 to $0.54 \mathrm{mmol} / \mathrm{mol} \mathrm{P}$. These quotas are almost one order of magnitude higher than the Cd quota observed by Martin and Knauer (1973) in the coastal plankton samples known to be dominated by diatom during spring bloom period. Once the biogenic particles formed in oceanic surface waters can reach deep water, the shift of microalgal community structure in oceanic surface water can be a potentially important factor in influencing dissolved $\mathrm{Cd} / \mathrm{P}$ ratios in deep waters when the structure change lasts long enough, particularly longer than the residence time of $\mathrm{Cd}$ and $\mathrm{P}$ in deep water.

It is puzzling why there are so divergent Cd quotas among different phytoplankton phyla or why some phytoplankton take up Cd strongly in oceanic surface waters. It seems to be unlikely that Cd uptake by phytoplankton is mainly due to $\mathrm{Zn}$ replacement. Both field and laboratory studies show that phytoplankton actively take up plenty of $\mathrm{Cd}$ even when the supply of $\mathrm{Zn}$ is adequate (Nolting et al., 1999; Whitfield, 2001; Ho et al., 2003). Our previous study on the elemental composition in various marine phytoplankton showed that there are two other cellular elements featured with extremely large composition ranges, which are $\mathrm{Ca}$ and $\mathrm{Sr}$ (Ho et al., 2003). The accidental uptake of elements with similar size charge ratios by phytoplankton may be important since trace metal transporters on algal cellular surfaces are seldom specific. The element with the closest size charge ratio to $\mathrm{Cd}^{2+}$ ion in the periodic table is $\mathrm{Ca}^{2+}$ ion, which is an essential and major element for all phytoplankton especially for coccolithophores and the species with $\mathrm{CaCO}_{3}$ cysts. It has also been known that $\mathrm{Cd}$ can inhibit $\mathrm{Ca}$ pump and membrane transport through fish studies (Verbost et al., $1988,1989 a, b)$; and the influx of Cd was significantly inhibited by a Ca channel blocker in mussels (Wang and Fisher, 1999), suggesting that $\mathrm{Cd}$ uptake in these organisms is related to Ca transporters or channels. Field studies in regions where coccolithophore is dominant found high Cd quotas in phytoplankton samples (Kuss and Kremling, 1999; Abe, 2005); culture studies show that calcareous algae are species with high $\mathrm{Cd}$ quotas and resistance to high $\mathrm{Cd}$ concentrations in seawater (Payne and Price, 1999; Sunda and Huntsman, 2000; Ho et al., 2003). Whether the strong microalgal $\mathrm{Cd}$ uptake and the highly varied $\mathrm{Cd} / \mathrm{P}$ quotas in phytoplankton are caused by accidental uptake through Ca transporters and channels deserves further studies.

The third factor to influence the $\mathrm{Cd} / \mathrm{P}$ ratios in sinking particles and seawater may be the aeolian supply of the soluble $\mathrm{Cd}$ and $\mathrm{P}$ in surface water. Dissolved concentrations of $\mathrm{Cd}$ and $\mathrm{P}$ in seawater were also determined when plankton was collected in 2002. The dissolved Cd/P ratios in the top $1000 \mathrm{~m}$ of seawater varied significantly (Fig. 8),

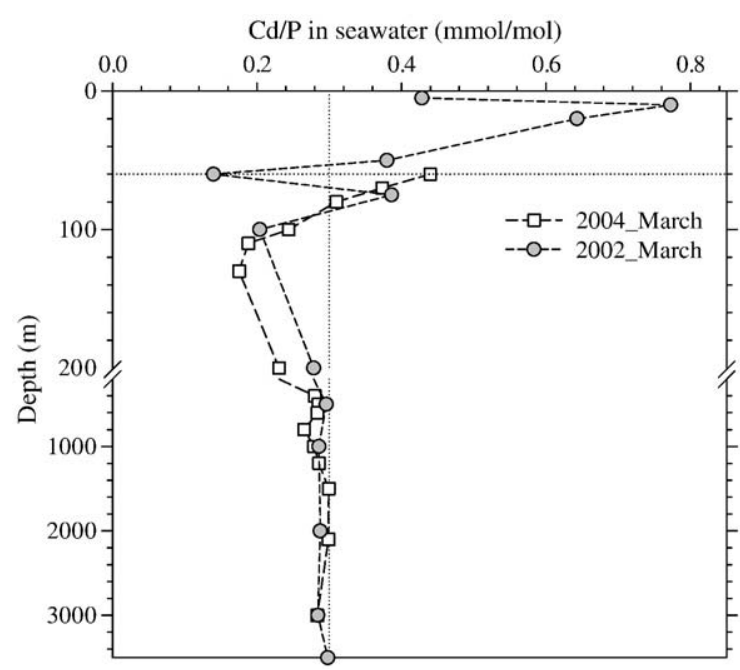

Fig. 8. The dissolved Cd/P ratios $(\mathrm{mmol} / \mathrm{mol})$ in seawater of the sampling site in March 2002 and 2004. The ratios are retrieved from the published data in Wen et al. (2006). 
with the highest ratio in the top $20 \mathrm{~m}(0.75 \mathrm{mmol} / \mathrm{mol})$ and lowest at a depth of $60 \mathrm{~m}(0.12 \mathrm{mmol} / \mathrm{mol})$. Aerosol input is the major allochthonous $\mathrm{Cd}$ sources in surface water. Our trace metal study of marine aerosols samples collected from the East China Sea shows that averaged deposition flux to the East China Sea during winter is around $10 \mathrm{nmol} / \mathrm{m}^{2} / \mathrm{d}$, which accounts for $5 \%$ of the Cd fluxes at the $120 \mathrm{~m}$ $\left(183 \mathrm{nmol} / \mathrm{m}^{2} / \mathrm{d}\right)$ for this study site. However, soluble $\mathrm{Cd} / \mathrm{P}$ ratios of aerosols ranged from 6 to $18 \mathrm{mmol} / \mathrm{mol}$ during winter (Ho et al. submitted), which is 20 to 60 fold of the average $\mathrm{Cd} / \mathrm{P}$ ratios in surface seawater. The high $\mathrm{Cd} / \mathrm{P}$ ratio in seawater could thus be caused by the input of aeolian aerosols with highly elevated $\mathrm{Cd} / \mathrm{P}$ ratios. In the long term, consistent input of elevated soluble $\mathrm{Cd}$ and $\mathrm{P}$ from aerosols to surface water may gradually influence $\mathrm{Cd} / \mathrm{P}$ ratios both for biogenic particles and seawater.

The lowest $\mathrm{Cd} / \mathrm{P}$ ratio in seawater was observed at the depth of chlorophyll-a maximum where size-fractionated plankton was collected. Since microalgal species were possibly dominated by coccolithophores during the sampling period of March 2002 and 2004 (Chen et al., 2007), the low Cd/P ratios in seawater at the depth of the chlorophyll- $a$ maximum may be caused by the preferential algal uptake of $\mathrm{Cd}$. In deep water, dissolved $\mathrm{Cd} / \mathrm{P}$ ratios in seawater were close to $0.3 \mathrm{mmol} / \mathrm{mol}$; the ratios are mainly controlled by preformed deep water based on global seawater horizontal segregation.

\section{Conclusion}

The major concern in using $\mathrm{Cd} / \mathrm{P}$ ratios as proxies in paleooceanography is whether the ratios in seawater may remain constant over a geological time scale (Saager and de Baar, 1993). Our study shows that $\mathrm{Cd} / \mathrm{P}$ ratios in sinking particles varied remarkably with time and depths in the sampling site. In the particles collected at $120 \mathrm{~m}$, the variability of the ratios was associated with changes of primary production and microalgal community structure. At the two deeper depths, increasing lithogenic particles greatly decreased the $\mathrm{Cd} / \mathrm{P}$ ratios in sinking particles. Several lines of evidences indicate that $P$ adsorption on mineral clays is an important process in influencing the ratios in the sinking particles of the water column. These two factors, including the change of phytoplankton community structure and $\mathrm{P}$ adsorption on mineral clays, can be important in influencing $\mathrm{Cd} / \mathrm{P}$ ratios not only in particles but also in seawater over a long term. Whether P adsorption by lithogenic particles occurs commonly in other marginal seas and open oceans, and how $\mathrm{P}$ adsorption by mineral clays quantitatively influences the ratios of $\mathrm{Cd} / \mathrm{P}$ and $\mathrm{N} / \mathrm{P}$ both in particles and seawater, and $\mathrm{P}$ residence time on a global scale all deserve further investigation.

\section{Acknowledgments}

We thank the personnel of the sediment trap laboratory of the National Sun Yat-Sen University, in particular Hui-Ling Lin and Francy Kuo, who were in charge of deploying the sediment traps and collecting the trap samples in the South China Sea. We thank W.-H. Lee and the personnel of the $R / V$ Ocean Research 1 and $R / V$ Ocean Research 3 for their assistance in sampling during the cruises and the research assistants at the Research Center for Environmental Changes (RCEC) for their help in laboratory analytical work. In particular, we thank Bing-Nan Wang, Wen-Chen Hsieh and Shiu-Ju Yang at the RCEC and Ying-Chun Lin at the Institute of Oceanography of the National Taiwan University for their assistance on the P analysis. This research was supported by grant numbers: NSC 93-2119-M-019-008, 94-2611-M019-020, 97-2628-M-001-031 by the Taiwan National Science Council, and thematic project AFOBi of Academia Sinica. The RCEC publication number is RCEC-HO-9801.

\section{References}

Abe, K., 2005. Apparent biological fractionation between $\mathrm{Cd}$ and $\mathrm{PO}_{4}$ in the surface waters of the equatorial Pacific Ocean. Mar. Chem. 96, 347-358.

Alldredge, A.L., Jackson, G.A., 1995. Aggregation in marine systems-preface. Deep-Sea Res. II 42, 1-7.

Benitez-Nelson, C.R., 2000. The biogeochemical cycling of phosphorus in marine systems. Earth Sci. Rev. 51, 109-135.

Boyle, E.A., 1988. Vertical oceanic nutrient fractionation and glacial interglacial $\mathrm{CO}_{2}$ cycles. Nature 331, 55-56.

Boyle, E.A., Sclater, F., Edmond, J.M., 1976. On the marine geochemistry of cadmium. Nature 263, 42-44.

Bruland, K.W., 1980. Oceanographic distributions of cadmium, zinc, nickel, and copper in the North Pacific. Earth Planet. Sci. Lett. 47, 176-198.

Bruland, K.W., Lohan, M.C., 2004. Controls of trace metals in seawater. In: Elderfield, H. (Ed.), The oceans and marine geochemistry. Elsevier Ltd, UK, pp. 23-47.

Bruland, K.W., Knauer, G.A., Martin, J.H., 1978. Cadmium in northeast Pacific waters. Limnol. Oceanogr. 23, 618-625.

Bruland, K.W., Donat, J.R., Hutchins, D.A., 1991. Interactive influences of bioactive tracemetals on biological production in oceanic waters. Limnol. Oceanogr. 36, 1555-1577.

Calvert, S.E., Pedersen, T.F., Thunell, R.C., 1993. Geochemistry of the surface sediments of the Sulu and South China Seas. Mar. Geol. 114, 207-231.

Chen, Y.L.L., 2005. Spatial and seasonal variations of nitrate-based new production and primary production in the South China Sea. Deep-Sea Res. 52, 319-340.

Chen, Y.L.L., Chen, H.Y., Chung, C.W., 2007. Seasonal variability of coccolithophore abundance and assemblage in the northern South China Sea. Deep-Sea Res. II 54 1617-1633.

Collier, R., Edmond, J., 1984. The trace-element geochemistry of marine biogenic particulate matter. Prog. Oceanogr. 13, 113-199.

Cullen, J.T., 2006. On the nonlinear relationship between dissolved cadmium and phosphate in the modern global ocean: could chronic iron limitation of phytoplankton growth cause the kink? Limnol. Oceanogr. 51, 1369-1380.

Cullen, J.T., Sherrell, R.M., 2005. Effects of dissolved carbon dioxide, zinc, and manganese on the cadmium to phosphorus ratio in natural phytoplankton assemblages. Limnol. Oceanogr. 50, 1193-1204.

Dyhrman, S.T., et al., 2006. Phosphonate utilization by the globally important marine diazotroph Trichodesmium. Nature 439, 68-71.

Edzwald, J.K., Toensing, D.C., Leung, M.C.Y., 1976. Phosphate adsorption reactions with clay minerals. Environ. Sci. Technol. 10, 485-490.

Finkel, Z.V., Quigg, A.S., Chiampi, R.K., Schofield, O.E., Falkowski, P.G., 2007. Phylogenetic diversity in cadmium: phosphorus ratio regulation by marine phytoplankton. Limnol. Oceanogr. 52, 1131-1138.

Fowler, S.W., Knauer, G.A., 1986. Role of large particles in the transport of elements and organic-compounds through the oceanic water column. Prog. Oceanogr. 16, 147-194.

Ho, T.Y., 2006. The trace metal composition of marine microalgae in cultures and natural assemblages. In: Subba Rao, D.V. (Ed.), Algal Cultures, Analogues of Blooms and Applications. Science Publishers, New Hampshire, pp. 271-299.

Ho, T.Y., et al., 2003. The elemental composition of some marine phytoplankton. J. Phycol. 39, 1145-1159.

Ho, T.Y., et al., 2004. The elemental composition of some marine phytoplankton (Corrigendum. vol 39, pg 1145, 2003). J. Phycol. 40, 227.

Ho, T.Y., Wen, L.S., You, C.F., Lee, D.C., 2007. The trace-metal composition of sizefractionated plankton in the South China Sea: biotic versus abiotic sources. Limnol. Oceanogr. 52, 1776-1788.

Knauer, G.A., Martin, J.H., 1981. Phosphorus-cadmium cycling in northeast Pacific waters. J. Mar. Res. 39, 65-76.

Kuss, J., Kremling, K., 1999. Spatial variability of particle associated trace elements in near-surface waters of the North Atlantic (30 degrees N/60 degrees W to 60 degrees N/2 degrees W), derived by large-volume sampling. Mar. Chem. 68, 71-86.

Lane, T.W., Morel, F.M.M., 2000. A biological function for cadmium in marine diatoms Proc. Natl. Acad. Sci. U S A 97, 4627-4631.

Lane, T.W., et al., 2005. A cadmium enzyme from a marine diatom. Nature 435, 42.

Li, Y.H., 1991. Distribution patterns of the elements in the ocean-a synthesis. Geochim. Cosmochim. Acta 55, 3223-3240.

Lin, I.I., Chen, J.P., Wong, G.T.F., Huang, C.W., Lien, C.C., 2007. Aerosol input to the South China Sea: results from the MODerate resolution imaging spectro-radiometer, the quick scatterometer, and the measurements of pollution in the troposphere sensor Deep-Sea Res. II 54, 1589-1601.

Löscher, B.M., de Jong, J.T.M., de Baar, H.J.W., 1998. The distribution and preferential biological uptake of cadmium at 6 degrees W in the Southern Ocean. Mar. Chem. 62 259-286.

Martin, J.H., Broenkow, W.W., 1975. Cadmium in plankton-elevated concentrations off Baja-California. Science 190, 884-885.

Martin, J.H., Knauer, G.A., 1973. Elemental composition of plankton. Geochim. Cosmochim. Acta 37, 1639-1653.

Martin, J.H., Bruland, K.W., Broenkow, W.W., 1976. Cadmium transport in the California current. In: Windom, H.L., Duce, R.A. (Eds.), Marine pollutant transfer. Lexington Books, USA, pp. 159-184.

Nolting, R.F., de Baar, H.J.W., Timmermans, K.R., Bakker, K., 1999. Chemical fractionation of zinc versus cadmium among other metals nickel, copper and lead in the northern North Sea. Mar. Chem. 67, 267-287.

Noriki, S., Hamahara, K., Harada, K., 1999. Particulate flux and Cd/P ratio of particulate material in the Pacific Ocean. J. Oceanogr. 55, 693-703.

Pace, M.L., Knauer, G.A., Karl, D.M., Martin, J.H., 1987. Primary production, new production and vertical flux in the eastern Pacific-Ocean. Nature 325, 803-804. 
Payne, C.D., Price, N.M., 1999. Effects of cadmium toxicity on growth and elemental composition of marine phytoplankton. J. Phycol. 35, 293-302.

Price, N.M., Morel, F.M.M., 1990. Cadmium and cobalt substitution for zinc in a marine diatom. Nature 344, 658-660.

Redfield, A.C., 1958. The biological control of chemical factors in the environment. Am. Sci. 46, 205-221.

Saager, P.M., de Baar, H.J.W., 1993. Limitations to the quantitative application of Cd as a paleoceanographic tracer, based on results of a multi-box model (MENU) and statistical considerations. Global Planet. Change 8, 69-92.

Sañudo-Wilhelmy, S.A., et al., 2001. Phosphorus limitation of nitrogen fixation by Trichodesmium in the central Atlantic Ocean. Nature 411, 66-69.

Sunda, W.G., Huntsman, S.A., 1996. Antagonisms between cadmium and zinc toxicity and manganese limitation in a coastal diatom. Limnol. Oceanogr. 41, 373-387.

Sunda, W.G., Huntsman, S.A., 1998. Control of Cd concentrations in a coastal diatom by interactions among free ionic Cd, Zn, and Mn in seawater. Environ. Sci. Technol. 32, 2961-2968.

Sunda, W.G., Huntsman, S.A., 2000. Effect of Zn, Mn, and Fe on Cd accumulation in phytoplankton: implications for oceanic Cd cycling. Limnol. Oceanogr. 45, 1501-1516.

Taylor, S.R., 1964. Abundance of chemical elements in the continental crust: a new table. Geochim. Cosmochim. Acta 28, 1273-1285.

Tseng, C.M., Wong, G.T.F., Lin, I.I., Wu, C.R., Liu, K.K., 2005. A unique seasonal pattern in phytoplankton biomass in low-latitude waters in the South China Sea. Geophys. Res. Lett. 32, L08608. doi:10.1029/2004GL022111.
Turekian, K.K., 1977. Fate of metals in oceans. Geochim. Cosmochim. Acta 41,1139-1144. Tyrrell, T., 1999. The relative influences of nitrogen and phosphorus on oceanic primary production. Nature 400, 525-531.

Verbost, P.M., Flik, G., Lock, R.A.C., Bonga, S.E.W., 1988. Cadmium inhibits plasmamembrane calcium-transport. J. Membr. Biol. 102, 97-104.

Verbost, P.M., Flik, G., Pang, P.K.T., Lock, R.A.C., Bonga, S.E.W., 1989a. Cadmium inhibition of the erythrocyte $\mathrm{Ca}^{2+}$ pump-a molecular interpretation. J. Biol. Chem. 264, 5613-5615.

Verbost, P.M Vanrooij, J., Flik, G, Lock, R.A.C, Bonga, S.E.W 1989b. The movement of cadmium through fresh-water trout branchial epithelium and its interference with calcium-transport. J. Exp. Biol. 145, 185-197.

Wang, W.X., Fisher, N.S., 1999. Effects of calcium and metabolic inhibitors on trace element uptake in two marine bivalves. J. Exp. Mar. Biol. Ecol. 236, 149-164.

Wen, L.S., Jiann, K.T., Santschi, P.H., 2006. Physicochemical speciation of bioactive trace metals (Cd, Cu, Fe, Ni) in the oligotrophic South China Sea. Mar. Chem. 101, 104-129.

Whitfield, M., 2001. Interactions between phytoplankton and trace metals in the ocean. Adv. Mar. Biol. 41, 1-128.

Wu, J.F., Sunda, W., Boyle, E.A., Karl, D.M., 2000. Phosphate depletion in the western North Atlantic Ocean. Science 289, 759-762.

Wu, C.R., Tang, T.Y., Lin, S.F., 2005. Intra-seasonal variation in the velocity field of the northeastern South China Sea. Cont. Shelf Res. 25, 2075-2083. 